RESEARCH REPORT

\title{
Effect of work related variables on growth among working boys in Jordan
}

\section{H Hawamdeh, N Spencer}

See end of article for authors' affiliations

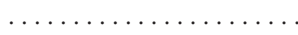

Correspondence to: Professor N Spencer, School of Postgraduate Medical Education.

University of Warwick, Coventry CV4 7AL, UK n.j.spencer@warwick.ac.uk

Accepted for publication 14 June 2002

\begin{abstract}
Objective: To study the effect of work related variables on the height, weight, and body mass index (BMI) of working boys aged 10-16 years.

Design: Cross sectional survey.

Setting: Irbid, Jarash, and North Jordan Valley in Jordan.

Participants: 135 working boys aged 10-16 years and their mothers.

Outcome measures: Height for age $z$ score; weight for age $z$ score; BMl for age $z$ score.

Results: In bivariate analysis, child's duration of work $(r=-0.20)$, maternal height $(r=0.26)$, and household per capita income $(r=0.23)$ were significantly correlated with height for age $z$ score and duration of work $(r=-0.24)$, maternal height $(r=0.24)$, and household per capita income $(r=0.19)$ with weight for age $z$ score. Duration of work $(p<0.001)$, child's monthly income $(p=0.044)$, maternal height $(p=0.002)$, and household per capita income $(p=0.005)$ were retained in the regression model fitted on height $z$ score that explained $20.1 \%$ of the variance. The regression model fitted on weight $z$ score explained $20.1 \%$ of the variance and duration of work $(p<0.001)$, child's monthly income $(p=0.022)$, household per capita income $(p=0.017)$, and maternal height ( $p=0.004)$ were retained. Only duration of work $(p=0.001)$ was retained in the model fitted on BMl for age $z$ score.

Conclusion: The results of this study suggest that the length of time children have been working and low monthly income have a detrimental effect on growth of working boys independent of the effects of low household per capita income and small maternal stature. Relevance of these findings for social policy and health care of working boys in Jordan and elsewhere is discussed.
\end{abstract}

with poorer growth. A further study ${ }^{10}$ suggests that weight slowdown occurs in working boys after the age of 12 and height slowdown after the age of 14. Body mass index (BMI) also decreased with increasing duration of employment.

This paper, based on the results of a cross sectional survey, reports the relation between growth and work related variables such as length of working week and duration of work among working boys in Jordan adjusted for the effects of family per capita income and maternal height.

\section{METHODS}

The study was conducted in three Jordanian areas, Irbid, Jarash, and North Jordan Valley, with a combined population of 1 million ( $20 \%$ of the total population). They contain a wide social range and are broadly representative of economic activity in Jordan from industry in Irbid to agriculture in North Jordan Valley. Jordan is a country in transition; its annual growth rate between 1960 and 1985 was $5.8 \%$ but between 1985 and 1995 there has been a negative annual rate of growth $(-4.5 \%) .{ }^{11}$ The GNP/capita was \$1510 in 1995. Between 1960 and 1995 the under 5 mortality rate fell from 139/1000 to $29 / 1000 .{ }^{11}$ Child labour may have increased as a result of the economic difficulties accompanying the declining growth rate.

\section{Definition of working child}

Waged and unwaged boys aged 10-16 years employed in economic activity in the study areas and not attending school. Working girls were excluded because of small numbers among working children in Jordan and the cultural constraints that made it more difficult for the male researcher $(\mathrm{HH})$ to approach them at their place of work.

\section{Sample selection}

Key local informants were interviewed to identify the sites and type of occupations undertaken by children in the study non-working children only became established after 8 years age suggesting that longer duration of work may be associated 
Table 1 Cohort and case-control studies examining the relation of child labour with growth

\begin{tabular}{|c|c|c|c|c|c|c|}
\hline Author/year & Study design & Setting & Exposure & Outcome & $\begin{array}{l}\text { Control for SES } \\
\text { and parental } \\
\text { height }\end{array}$ & Conclusion \\
\hline $\begin{array}{l}\text { Japanese study } \\
\text { reported in Shah } \\
1984^{2}\end{array}$ & Case-control & Japan & $\begin{array}{l}\text { Children starting work } \\
\text { at } 14 v \text { those starting } \\
\text { work at } 18\end{array}$ & Height & $\begin{array}{l}\text { No attempt to } \\
\text { adjust for SES or } \\
\text { parental height }\end{array}$ & $\begin{array}{l}4 \mathrm{~cm} \text { difference in height between } \\
\text { cases and controls }\end{array}$ \\
\hline $\begin{array}{l}\text { Satyanarayana et } \\
\text { al } 1985^{3}\end{array}$ & $\begin{array}{l}\text { Cohort (17 year } \\
\text { follow up) }\end{array}$ & Hyderabad, India & $\begin{array}{l}\text { Child farmers in } \\
\text { families; waged farm } \\
\text { workers; non-farm } \\
\text { workers; students }\end{array}$ & $\begin{array}{l}\text { Height and } \\
\text { weight }\end{array}$ & $\begin{array}{l}\text { No attempt to } \\
\text { adjust for SES or } \\
\text { parental heightt }\end{array}$ & $\begin{array}{l}\text { Height and weight lower in workers } \\
\text { compared with students; deficit in } \\
\text { height and weight greater in waged } \\
\text { than children working in family. }\end{array}$ \\
\hline Singh et al $1980^{5}$ & Case-control & Bombay, India & $\begin{array}{l}\text { Working } v \\
\text { non-working children } \\
\text { in slums }\end{array}$ & Height & $\begin{array}{l}\text { No attempt to } \\
\text { adjust for SES or } \\
\text { parental height }\end{array}$ & $\begin{array}{l}\text { Height of working children lower } \\
\text { than non-working controls; children } \\
\text { starting to work before } 9 \text { years } \\
\text { more stunted than those starting at } \\
\text { age } 11 \text {. }\end{array}$ \\
\hline Gross et al $1996^{\circ}$ & Case-control & Jakarta, Indonesia & $\begin{array}{l}\text { Working street } \\
\text { children } v \text { non-working } \\
\text { slum children }\end{array}$ & $\begin{array}{l}\text { Height for age; } \\
\text { weight for age; } \\
\text { weight for } \\
\text { height }\end{array}$ & $\begin{array}{l}\text { No attempt to } \\
\text { adjust for SES or } \\
\text { parental height }\end{array}$ & $\begin{array}{l}52 \% \text { of street children }<3 \text { rd centile } \\
\text { for height by NCHS reference } \\
\text { standards; } 7 \%<3 \text { rd centile for } \\
\text { weight. Height and weight of street } \\
\text { children }>\text { slum children }\end{array}$ \\
\hline $\begin{array}{l}\text { Joshi and Sharma } \\
1996^{4}\end{array}$ & Case-control & Jaipur City, India & $\begin{array}{l}110 \text { working children } \\
\text { v } 290 \text { school children } \\
\text { matched for age and } \\
\text { area }\end{array}$ & Height; weight & $\begin{array}{l}\text { No adjustment } \\
\text { for SES or } \\
\text { parental height }\end{array}$ & $\begin{array}{l}\text { Height and weight controlled by } \\
\text { age < in working children except } \\
\text { among } 6-8 \text { year olds in whom no } \\
\text { difference noted }\end{array}$ \\
\hline $\operatorname{Lee}^{18}$ & Case-control & Republic of Korea & $\begin{array}{l}593 \text { female factory } \\
\text { workers }<18 \text { years } v \\
109 \text { girls applying for } \\
\text { work }\end{array}$ & Height; weight & $\begin{array}{l}\text { No attempt to } \\
\text { adjust for SES or } \\
\text { parental height }\end{array}$ & $\begin{array}{l}\text { Working girls taller and heavier } \\
\text { than controls }\end{array}$ \\
\hline Mahathevan ${ }^{7}$ & Case-control & Malaysia & $\begin{array}{l}210 \text { working children } \\
(7-15 \text { y) v } 210 \text { age, } \\
\text { sex, ethnic group and } \\
\text { SES matched school } \\
\text { children }\end{array}$ & Weight & $\begin{array}{l}\text { No adjustment } \\
\text { for parental } \\
\text { height }\end{array}$ & $\begin{array}{l}48 \% \text { of working children } \\
\text { "underweight" but no figures given } \\
\text { for controls }\end{array}$ \\
\hline Sampa $1993^{8}$ & Case-control & Calcutta, India & $\begin{array}{l}40 \text { boys }(7-14 \text { y) } \\
\text { working in leather } \\
\text { workshops } v 40 \text { age, } \\
\text { area and SES matched } \\
\text { controls }\end{array}$ & Height; weight & $\begin{array}{l}\text { No adjustment } \\
\text { for parental } \\
\text { height }\end{array}$ & $\begin{array}{l}\text { No height or weight differences } \\
\text { between cases and controls }\end{array}$ \\
\hline De La Pas $1990^{\circ}$ & Case-control & Philippines & $\begin{array}{l}113 \text { working } v 109 \\
\text { non-working boys } \\
\text { matched for age and } \\
\text { area }\end{array}$ & $\begin{array}{l}\text { Height; weight; } \\
\text { sitting height }\end{array}$ & $\begin{array}{l}\text { Adjustment for } \\
\text { SES but not for } \\
\text { parental height }\end{array}$ & $\begin{array}{l}\text { Height and weight differences } \\
\text { between cases and controls } \\
\text { disappeared on adjustment for SES; } \\
\text { working hours and number of } \\
\text { working days not correlated with } \\
\text { growth parameters measured }\end{array}$ \\
\hline $\begin{array}{l}\text { Ambadekar et al } \\
1999^{10}\end{array}$ & Case-control & $\begin{array}{l}\text { Maharashtra, } \\
\text { India }\end{array}$ & $\begin{array}{l}223 \text { working children } \\
\text { (8-15 y) v } 223 \text { age } \\
\text { and gender matched } \\
\text { non-working controls }\end{array}$ & $\begin{array}{l}\text { Height; weight; } \\
\text { BMI }\end{array}$ & $\begin{array}{l}\text { No adjustment } \\
\text { for SES or } \\
\text { parental height }\end{array}$ & $\begin{array}{l}\text { Mean height and weight of working } \\
\text { boys increased less than } \\
\text { non-working boys - for weight } \\
\text { slowdown occurred in working } \\
\text { boys after } 12 \text { years and after } 14 \\
\text { yrs for ht. Girls showed no } \\
\text { significant differences. BMI } \\
\text { decreased with increasing duration } \\
\text { of employment. }\end{array}$ \\
\hline
\end{tabular}

areas. Each study area was then systematically mapped to children's workplaces. The researcher $(\mathrm{HH})$ then carried out detailed observation of each study area during daytime and evening hours recording frequency of different types of child labour. Three broad categories of child labour were identified: industrial (mainly in Irbid); service and commercial (mainly in Jarash); agricultural (mainly in North Jordan Valley). Sampling was stratified so that each category of child labour was represented in the study sample in proportion to its size in the three study areas. The stratified study sample of 135 working children included 75 in Irbid (60 in the industrial and 15 in the service sectors), 35 in Jarash (25 in the service and 10 in the industrial sectors), and 25 in the North Jordan Valley (all in the agricultural sector). After an approach to the employer, working boys, who were present at the workplace during sampling recruitment visits, were enrolled into the study. There were few study refusers once employers had given their consent. Parental consent was obtained after full explanation of the purpose of the study. Difficulties had been experienced in obtaining consent during the pilot study, which proved to be related to parental concern that the information might be passed to government officials. In the main study, parents were reassured that the information was confidential and that the data would not be shared with government departments.

\section{Data collection}

Working boys were interviewed in the home with their parents using a structured interview schedule pre-tested in a pilot study. Data on the following exposures were collected: length of working week in hours; monthly income earned by the child in Jordanian dinars (JDs); duration of work in years; age in years of starting work; type of work (industrial, service, or agricultural); child's smoking status ( $\geqslant 5$ cigarettes/day-yes/ no); family per capita monthly income in JDs. Maternal height, as a proxy for mid-parental height, was measured at the end of the interview. Data were not available on height of fathers and fathers were rarely present at the time of the interview. Although child's income is part of family income, there is evidence from a study in Indonesia suggesting that child's income may be used to purchase food for their own consumption and not always pooled with family income. For this reason, it was decided to enter child's income as an independent variable into the analysis. Outcome variables collected were height $(\mathrm{cm})$, measured using a portable tape, 
Table 2 Family sociodemographic characteristics of working boys

\begin{tabular}{|c|c|}
\hline Family characteristics & Working boys $(n=135)$ \\
\hline \multicolumn{2}{|l|}{ Family size: } \\
\hline$\leqslant 4$ & $5(3.7 \%)$ \\
\hline $5-7$ & $31(23.0 \%)$ \\
\hline $8-10$ & $57(42.2 \%)$ \\
\hline$>10$ & $42(31.1 \%)$ \\
\hline mean $(95 \% \mathrm{CI})$ & 9.7 (9.07 to 10.33$)$ \\
\hline range & $4-30$ \\
\hline \multicolumn{2}{|c|}{ Household per capita income (JD/month): } \\
\hline$\leqslant 20$ & $31(23.0 \%)$ \\
\hline $21-41$ & $68(50.3 \%)$ \\
\hline $42-60$ & $21(15.6 \%)$ \\
\hline$>60$ & $15(11.1 \%)$ \\
\hline mean $(95 \% \mathrm{Cl})$ & $36.4(32.9$ to 39.9$)$ \\
\hline range & $10-150$ \\
\hline \multicolumn{2}{|l|}{ House $\mathrm{m}^{2}$ per capita: } \\
\hline$\leqslant 20$ & $104(77.0 \%)$ \\
\hline$>20$ & $31(23.0 \%)$ \\
\hline mean $(95 \% \mathrm{Cl})$ & 15.6 (14.4 to 16.8 ) \\
\hline range & $0-35$ \\
\hline \multicolumn{2}{|c|}{ Household durable expenditure (JD): } \\
\hline $0-14$ & $87(64.4 \%)$ \\
\hline $15-36$ & $33(24.4 \%)$ \\
\hline$>36$ & $15(11.2 \%)$ \\
\hline mean $(95 \% \mathrm{Cl})$ & 24.5 (20.1 to 28.9 ) \\
\hline range & $0-108$ \\
\hline \multicolumn{2}{|c|}{ Occupation of head of household: } \\
\hline Unskilled & 77 (57\%) \\
\hline Semiskilled & $51(37.8 \%)$ \\
\hline Skilled & $7(5.2 \%)$ \\
\hline \multicolumn{2}{|l|}{ Father's education level: } \\
\hline Illiterate & $12(8.9 \%)$ \\
\hline Lower education & $113(83.7 \%)$ \\
\hline Higher education & $10(7.4 \%)$ \\
\hline \multicolumn{2}{|l|}{ Mother's education level: } \\
\hline Illiterate & $36(26.7 \%)$ \\
\hline Lower education & 89 (65.9\%) \\
\hline Higher education & $10(7.4 \%)$ \\
\hline
\end{tabular}

expressed as a $\mathrm{Z}$ score using LMS software based on UK standards $^{12}$ and weight $(\mathrm{kg})$, measured using Detecto adult scales, expressed as a z score using LMS software based on UK standards. ${ }^{12}$ BMI (weight $(\mathrm{kg}) /$ height $\left(\mathrm{m}^{2}\right)$ was expressed as a $\mathrm{z}$ score using the same software. ${ }^{12}$

\section{Data analysis}

Simple correlation coefficients of exposure on outcome variables were estimated. Linear regression models were fitted on height, weight, and BMI z scores using SPSS v.8.0. ${ }^{13}$ All exposure variables, whether or not they achieved conventional levels of statistical significance on bivariate analysis, were entered into the regression analysis. The $r^{2}$ (the proportion of the variance explained by the model) and the regression coefficient $\beta$ (change in the outcome associated with a change of one unit in the exposure variable) for each exposure were estimated for the models fitted on both outcomes. Only variables achieving a significance level of $<0.05$ were retained in the final model. Residuals were plotted for the regression models.

\section{RESULTS}

Permission to enrol their employees into the study was denied by 3 of $64(4.7 \%)$ employers. Two mothers refused to be measured. These missing maternal height data were given values equivalent to the mean for the whole sample according to the method described by Katz. ${ }^{14}$ Data on 135 working boys were available for analysis. The family, work, and socioeconomic characteristics of the sample are shown in table 2 and are reported in detail in a related paper. ${ }^{15}$

Correlation coefficients of exposure variables on outcomes are shown in table 3. Duration of work in years, maternal height, and household per capita income showed a statistically significant correlation with height for age z score. Duration of work, age of starting work, maternal height, and household per capita income were also significantly correlated with weight for age z score. Only duration of work and age of starting work were correlated with BMI for age z score.

To explore the association between age of starting work and low household income, the correlation between age of starting work and total household monthly income minus child's monthly income was estimated. There was no significant correlation $(r=-0.08)$.

The regression model fitted on height $\mathrm{z}$ score (table 4) explains $20.1 \%$ of the variance $\left(r^{2}=0.201\right)$ : duration of work in years explains $9.1 \%$ and each year of work is associated with a $\mathrm{Z}$ score reduction of 0.31 ; maternal height explains $6.0 \%$ of the variance and $1 \mathrm{~cm}$ increase is associated with an increase in $\mathrm{z}$ score of 0.07 ; family per capita income explains $5.0 \%$ of the variance with an increase of $1 \mathrm{JD} /$ month associated with a $\mathrm{z}$ score increase of 0.01; monthly income of the child explains $2.5 \%$ of the variance and for each $1 \mathrm{JD}$ rise there is an associated $\mathrm{z}$ score increase of 0.01 .

For weight $\mathrm{z}$ score (table 5 ), the regression model explains $20.1 \%$ of the variance $\left(r^{2}=0.201\right): 11.3 \%$ of the variance was explained by duration of work with 0.33 reduction in $\mathrm{z}$ score for each additional year worked; $5.3 \%$ of the variance was explained by maternal height with 0.06 increase in z score for each additional $\mathrm{cm}$ of maternal height; the child's monthly income explains a further $3.4 \%$ of the variance with 0.01 increase in z score for each additional JD earned; the family per capita income accounts for $4.6 \%$ of the variance with a 0.0 lincrease in weight $\mathrm{z}$ score for each additional JD.

Only duration of work was retained in the final model for BMI for age $\mathrm{z}$ score. The model explained $9 \%$ of the variance $\left(r^{2}=0.09\right)$ with 0.24 reduction in $\mathrm{z}$ score with each additional year worked.

The plots of residuals in the models were close to normal distribution.

Table 3 Bivariate correlation (Pearson coefficients) of exposure on outcome variables

\begin{tabular}{llll}
\hline Exposure & $\begin{array}{l}\text { Height for age z } \\
\text { score }\end{array}$ & $\begin{array}{l}\text { Weight for age } \\
\text { z score }\end{array}$ & $\begin{array}{l}\text { BMI for age z } \\
\text { score }\end{array}$ \\
\hline Type of job (industrial/service/agricultural) & -0.03 & -0.10 & -0.13 \\
Duration of work (y) & $-0.20^{*}$ & $-0.24^{* *}$ & $-0.23^{*}$ \\
Age at starting work & 0.05 & $0.18^{*}$ & $0.24^{* *}$ \\
Working hours per week & 0.03 & 0.06 & 0.03 \\
Child's monthly income & 0.07 & 0.07 & 0.02 \\
Household per capita income & $0.23^{*}$ & $0.14^{*}$ & 0.09 \\
Smoking (>5 cigarettes/day) & -0.02 & 0.02 & 0.03 \\
Maternal height $(\mathrm{cm})$ & $0.26^{*}$ & $0.24^{*}$ & 0.11 \\
\hline
\end{tabular}

0.24 
Table 4 Final regression model fitted on height $z$ score

\begin{tabular}{|c|c|c|c|c|}
\hline Independent variables in final model & $\begin{array}{l}\text { Unstandardised coefficient } \beta \\
(95 \% \mathrm{CI})\end{array}$ & t Statistic & $\mathrm{p}$ Value & $\begin{array}{l}\mathrm{r}^{2} \text { (\% of variance explained } \\
\text { by each independent } \\
\text { variable) }\end{array}$ \\
\hline (Constant) & $-11.02(-17.75$ to -4.28$)$ & -3.24 & 0.002 & \\
\hline Duration of work (y) & $-0.31 \quad(-0.48$ to -0.15$)$ & -3.85 & $<0.001$ & $0.090(9.0)$ \\
\hline Child's monthly income (JDs) & $0.01 \quad(0.00$ to 0.02$)$ & 2.03 & 0.044 & $0.025(2.5)$ \\
\hline Maternal height $(\mathrm{cm})$ & $0.07(0.02$ to 0.11$)$ & 3.11 & 0.002 & $0.060(6.0)$ \\
\hline Household income/capita (JDs) & $0.01 \quad(0.00$ to 0.02$)$ & 2.86 & 0.005 & $0.050(5.0)$ \\
\hline Final model & & & & $0.201(20.1)$ \\
\hline
\end{tabular}

Table 5 Final regression model fitted on weight $\mathrm{z}$ score

\begin{tabular}{|c|c|c|c|c|}
\hline Independent variables in final model & $\begin{array}{l}\text { Unstandardised coefficient } \beta \\
(95 \% \mathrm{Cl})\end{array}$ & t Statistic & $\mathrm{p}$ Value & $\begin{array}{l}\mathrm{r}^{2} \text { (\% of variance explained } \\
\text { by each independent } \\
\text { variable) }\end{array}$ \\
\hline (Constant) & $-9.35(-15.65$ to -3.05$)$ & -2.94 & 0.004 & \\
\hline Duration of work (y) & $-0.33(-0.48$ to -0.18$)$ & -4.29 & $<0.001$ & $0.113(11.3)$ \\
\hline Child's monthly income (JDs) & $0.02(0.00$ to 0.02$)$ & 2.32 & 0.022 & $0.034(3.4)$ \\
\hline Maternal height $(\mathrm{cm})$ & $0.06(0.02$ to 0.10$)$ & 2.93 & 0.004 & $0.053(5.3)$ \\
\hline Household income/capita (JDs) & $0.01 \quad(0.00$ to 0.02$)$ & 2.42 & 0.002 & $0.046(4.6)$ \\
\hline Final model & & & & $0.201(20.1)$ \\
\hline
\end{tabular}

\section{Key points}

- Growth impairment is associated with duration of work and low monthly child income independent of household per capita income or maternal height.

- Laws protecting children from exploitation through work exist in most countries but are not enforced.

- Protection of working children may need initiatives aimed at nutritional and educational outreach alongside more effective law enforcement.

\section{DISCUSSION}

The results of this study suggest that, independent of maternal height and family income per capita, work related variables, such as duration of work and child's monthly income, have an effect on growth in height and weight. BMI is affected only by duration of work. Another plausible explanation of these findings is that the poorest children who are likely to be the most growth retarded before starting work have the greatest economic pressure to work. As this is a cross sectional survey, it is not possible to completely refute this alternative explanation. If this alternative explanation were true, as a result of the need for the poorest children to work as early as possible, a correlation would be expected between age of starting work and the family income excluding the child's income. No such correlation was found. In addition, as we have reported elsewhere from the same study, ${ }^{16}$ working boys have significantly lower height for age and weight for age $\mathrm{z}$ scores than their non-working male siblings. The findings are also consistent with those of the few studies reporting the relation between growth and duration of working in childhood. ${ }^{4}{ }^{10}$

There is a plausible physiological explanation for these findings. The higher physical activity associated with work requires additional nutrients to compensate for additional calorie consumption especially during periods of increased growth such as puberty. If the child's income is required to supplement household income, it is probable that insufficient compensatory calories will be available for normal growth. The finding that growth differences between working and non-working children did not become established until after 8 years of age $e^{4}$ lends support to this explanation. Further support comes from a study of street children in Jakarta ${ }^{6}$ whose growth was better than non-working children from the same poor neighbourhoods; the authors suggest that the street children were able to use their incomes entirely for the purchase of additional calories rather than sharing them with other household members.

While there is an extensive literature on the characteristics of work among children and the general health hazards of work, ${ }^{34817}$ a comprehensive literature review has failed to identify any reports of studies examining the relation of duration of work and child's income with child growth.

\section{Limitations of the study}

Child labour is illegal in many countries including Jordan although the law is not enforced. As a consequence, children's work is frequently hidden making the selection of a representative sample difficult. Despite the systematic sampling method used in this study, it is probable that some types of child labour are under-represented. It is probable that child labour within the family is under-represented. Impairment of growth may be less likely in the comparatively protected family environment. However, more hidden forms of child labour outside the family in less protected environments are also likely to be under-represented and these forms of labour may carry an increased risk of growth impairment.

Stage of puberty was not assessed. It is possible, though unlikely, that this introduced a systematic bias among working boys such that those with shorter work histories were more likely to enter puberty early thus confounding the relation between work duration and height $\mathrm{z}$ score.

The regression models for height and weight $\mathrm{z}$ scores account for only $20.1 \%$ of the variance and $9 \%$ for BMI. Other factors not measured in this study exert an influence on growth among working children. Some of these unknown variables may be confounding the apparent independent effect of work related variables on growth. For example, it is possible, although unlikely, that children sent to work at an early age are victimised within the family leading to growth impairment. Residual confounding by socioeconomic status 
may also account for some of the apparent independent effect of work related exposures.

As considered above, this is a cross sectional survey and we cannot rule out alternative explanations for the relation between growth and work related variables found in this study. Longitudinal study design would be necessary to resolve these conflicting explanations.

\section{Conclusions}

Despite these limitations, the results of this study suggest that, within a group of working children, duration of work is associated with growth impairment and higher monthly income protects against some of the detrimental effects of work on growth. These effects seem to be independent of family per capita income and maternal height.

These findings have social policy implications for Jordan and probably for other countries with high levels of child labour. Despite strict laws prohibiting child labour, it remains a common problem globally flourishing among poverty and low levels of education. To minimise the intergenerational cycle of child labour leading to illiteracy, social policies aimed at reducing poverty and ensuring basic levels of literacy and educational and nutritional outreach to child workers are likely to be more effective than simply attempting to enforce laws.

\section{Contributors}

$\mathrm{HH}$ and NS jointly designed the study which forms the basis of HH's $\mathrm{PhD}$. HH collected the data. HH analysed the data with guidance from NS. HH and NS jointly wrote the paper. NS is the guarantor.

\section{Authors' affiliations}

H Hawamdeh, N Spencer, School of Postgraduate Medical Education, University of Warwick, Coventry, UK

Funding: none.

Conflicts of interest: none.

\section{REFERENCES}

1 Habenicht $\mathbf{H}$. The international programme on the elimination of child labour: an international response to child labour. International Child Health: a digest of current information 1994; V:19-25.

2 Shah PM. The health care of working children. Child Abuse Negl 1984;8:541-4.

3 Satayanarayana K, Prasanna KT, Narasinga RBS. Effect of early childhood undernutrition and child labour on growth and adult nutritional status of rural Indian boys around Hyderabad. Human Nutrition:Clinical Nutrition 1985;40:131-9.

4 Joshi SK, Sharma P. Peak expiratory flow rate of carpet weaving children. Indian Pediatr 1996;33:105-8.

5 Singh M, Kaura VD, Khan SA. Working children in Bombay- a study. New Delhi, India: National Institute of Public Cooperation and Child Development, 1980

6 Gross R, Landfried B, Herman S. Height and weight as a reflection of the nutritional situation of school-aged children working and living in the streets of Jakarta. Soc Sci Med 1996:43:453-8.

7 Mahathevan R. A register of children at work. In: Children at work:special health risks. Technical Report Series no 756. Geneva: WHO, 1987;13-17.

8 Sampa M. A study of the health conditions of child workers in a small scale leather industry in Calcutta. Br J Ind Med 1993;50:938-40.

9 De La Paz, M.M. Child labour: its implication for nutrition and health in the Philippines. [PhD thesis]. Cornell University, 1990.

10 Ambadekar NN, Wahab SN, Zodpey SP, et al. Effect of child labour on growth of children. Public Health 1999;113:303-6.

11 Bellamy C. The state of the world's children 1998. Oxford: Oxford University Press for UNICEF, 1998.

12 Child Growth Foundation. LMS software using 1990 British height and weight reference data. London, Child Growth Foundation, 1999.

13 SPSS. SPSS for Windows, Version 8.0. Chicago: SPSS, 1998.

14 Katz MH. Multivariable analysis: a practical guide for clinicians. Cambridge: Cambridge University Press, 1999

15 Hawamdeh H, Spencer NJ. Work, family socioeconomic status and growth among working boys in Jordan. Arch Dis Child 2001;84:311-14.

16 Hawamdeh H, Spencer NJ. Growth of working boys in Jordan: a cross-sectional survey using non-working male siblings as comparisons. Child Care health Dev 2002;28:47-9.

17 Asogwa SE. Sociomedical aspects of child labour in Nigeria. J Occup Med 1986;28:46-8.

18 Lee SH. A cross-sectional survey of child workers in industry. In: Children at work: special health risks. Technical report series no 756. Geneva: WHO, 1987:18-21. 